\title{
Down-regulation of the candidate tumor suppressor gene $P A R-4$ is associated with poor prognosis in breast cancer
}

\author{
MARIA APARECIDA NAGAI ${ }^{1}$, RENÊ GERHARD $^{1}$, SIBELI SALAORNI $^{1}$, \\ JOSÉ HUMBERTO TAVARES GUERREIRO FREGNANI ${ }^{2}$, SUELY NONOGAKI ${ }^{3}$, \\ MÁRIO MOURÃO NETTO ${ }^{4}$ and FERNANDO AUGUSTO SOARES ${ }^{4}$ \\ ${ }^{1}$ Disciplina de Oncologia, Departamento de Radiologia da Faculdade de Medicina da Universidade de São Paulo, \\ Av. Dr. Arnaldo 455, $4^{\circ}$ andar, CEP 01246-903, São Paulo; ${ }^{2}$ Departamento de Ginecologia Oncológica e \\ Centro de Apoio à Pesquisa, Hospital de Câncer de Barretos, Barretos; ${ }^{3}$ Instituto Adolfo Lutz, Divisão de Patologia; \\ ${ }^{4}$ Fundação Antonio Prudente, Rua Professor Antonio Prudente 211, CEP 01509-900, São Paulo, Brazil
}

Received November 30, 2009; Accepted February 24, 2010

DOI: 10.3892/ijo_00000651

\begin{abstract}
Substantial experimental evidence indicates that $P A W R$ gene (PKC apoptosis WT1 regulator; also named PAR-4, prostate apoptosis response-4) is a central player in cancer cell survival and a potential target for cancer-selective targeted therapeutics. However, little is known about the role of PAR-4 in breast cancer. We investigated the possible role of PAR-4 expression in breast cancer. IHC results on tissue microarrays containing 1,161 primary breast tumor samples showed that $57 \%(571 / 995)$ of analyzable cases were negative for PAR-4 nuclear staining. Down-regulation of nuclear PAR-4 protein expression predicted a poor prognosis for breast cancer patients (OS; $\mathrm{P}=0.041$, log-rank test). PAR-4 down-regulation also correlates with poor survival in the group of patients with luminal A subtype breast cancer $(\mathrm{P}=0.028)$. Additionally, in this large series of breast cancer patients, we show that ERBB2/HER2, EGFR and pAKT protein expression are significantly associated with shorter diseasefree survival and overall survival, but the prognosis was even worse for HER2-positive, EGFR-positive or pAKT-positive breast cancer patients with tumors negative for nuclear PAR-4 expression. Furthermore, using three-dimensional (3D) cell culture we provide preliminary results showing that PAR-4 is highly expressed in the MCF10A cells inside the acini structure, suggesting that PAR-4 might have a role in the lumen acini formation. Taken together, our results provide, for the first time, evidence that PAR-4 may have a role in the process of the mammary gland morphogenesis and its
\end{abstract}

Correspondence to: Dr Maria Aparecida Nagai, Disciplina de Oncologia, Departamento de Radiologia da Faculdade de Medicina da Universidade de São Paulo, Av. Dr. Arnaldo, 455, $4^{\circ}$ andar, CEP 01246-903, São Paulo, Brazil

E-mail: nagai@usp.br

Key words: breast cancer, $P A R-4$, tissue microarrays, immunohistochemistry, 3D cell culture, molecular marker functional inactivation is associated with tumor aggressive phenotype and might represent an additional prognostic and predictive marker for breast cancer.

\section{Introduction}

Evasion of apoptosis (programmed cell death), which is an active, energy-dependent process involving biochemical and molecular events regulated by a series of distinct genes is a hallmark of cancer (1). Down-regulation of apoptotic rates is associated with tumor pathogenesis and affects chemo- and radioresistance (2). Much experimental evidence indicates that PAWR (PKC apoptosis WT1 regulator; also named PAR-4, prostate apoptosis response-4) is one of the central players in cancer cell survival and could be a target for cancer-selective targeted therapeutics (3). The PAR-4 gene is located at chromosome 12q21 and encodes a $38-\mathrm{kDa}$ protein containing two nuclear localization signals (NLS), a leucine zipper domain, and a selective apoptosis induction in cancer cells (SAC) domain (4-6). The PAR-4 was first identified as being up-regulated in androgen-independent prostate cancer cells undergoing apoptosis after treatment with calcium (7).

The PAR-4 protein contains conserved amino acid residues that are the target of phosphorylation by protein kinases $\mathrm{A}$ (PKA) and $\mathrm{C}(\mathrm{PKC})$, which regulate its sub-cellular localization and possibly its ability to dimerize with other proteins $(3,8)$. The PAR-4 protein binds to and forms complexes with various proteins, including PKC $\xi$, WT-1, ZIPK, DAXX, and THAP1 through its C-terminal leucine zipper domain to affect cell survival (9-12). There is evidence that PAR-4 displays its pro-apoptotic activity by down-regulating the anti-apoptotic Bcl-2 protein $(13,14)$. In addition, experimental studies showed that PAR-4 induces apoptosis through its ability to activate the pro-death, FasL-Faz-FADD-caspase 8 pathway and by inhibiting the NF- $\mathrm{KB}$ pro-survival pathway, which requires phosphorylation of PAR-4 at T155 mediated by PKA activity $(12,15,16)$. On the other hand, AKT activity, which is elevated in cancer cells through growth factor signaling stimulation, oncogene activation, or loss of the phosphatase and tensin homolog (PTEN) tumor suppressor activity can inhibit PAR-4's 
pro-apoptotic function (17). Goswami et al demonstrated that AKT binds to the PAR-4 protein and phosphorylates PAR-4 at residue $\mathrm{S} 249$, with subsequent sequestration of PAR-4 in the cytoplasm by the chaperone 14-3-3 proteins, which inhibit PAR-4's apoptotic activity (18).

The PAR-4 gene is expressed in several mammalian cells including mammary-gland epithelial cells $(19,20)$. Expression of PAR-4 may increase the sensitivity of most cancer cells to apoptosis, especially in hormone-independent cancer cell lines, including breast cancer cells $(6,15)$. PAR-4 protein expression is induced by many conditions, such as growth factor withdrawal, $T N F$, ionizing radiation and high levels of calcium $(4,20-22)$. In cultured embryonic rat hippocampal neurons, withdrawal of trophic factors increases the level of PAR-4 mRNA expression (23).

Alterations in PAR-4 mRNA and protein expression were observed in different types of tumors. In hematopoietic cells, this gene exhibits an anti-tumor effect and induces increased sensitivity towards chemotherapeutic agents (24). Decreased PAR-4 protein levels were demonstrated in human renal carcinomas and human renal cancer cells (25). Reduced expression of PAR-4 due to promoter hypermethylation is a frequent event associated with endometrial carcinogenesis (26). PAR-4 down-regulation was associated with K-ras mutation and a poor prognosis in pancreatic tumors (27). The role of PAR-4 in prostate cancer has been well described $(15,28)$.

To date, little is known of the role played by PAR-4 in breast cancer. In the present study, using immunohistochemisty (IHC) on tissue microarrays (TMAs) in a large series of tumor samples, our purpose was to determine whether PAR-4 protein expression has prognostic significance in breast cancer patients. We also attempted to correlate PAR-4, EGFR, ERBB2/HER2, and $\mathrm{pAKT}$ protein expression with clinical outcomes in breast cancer patients. In addition, preliminary results with MCF10A mammary epithelial cells using 3D cell culture suggest that PAR-4 might have a role for the lumen acini formation.

\section{Materials and methods}

Tissue samples and patients characteristics. Primary breast tumor samples were obtained from 1,161 patients with invasive ductal carcinoma at the Department of Pathology, Hospital AC Camargo, São Paulo, Brasil. All patients were diagnosed at the hospital and treated at same institution by radical mastectomy, modified radical mastectomy or breast-conserving surgery including axillary lymph node dissection. The median age of the patients at the time of diagnosis was 54 (range 24-96) years. The sizes of the tumors ranged from 0.4 to $22 \mathrm{~cm}$ (median 4) $\mathrm{cm}$. Table I lists the patient characteristics. The Institutional Ethics Committee approved this study and all patients provided informed consent.

Tissue microarrays (TMA) construction. For TMA construction, formalin-fixed, paraffin-embedded tissue blocks containing invasive breast cancer from 1,161 patients were retrieved from the archives. New sections from each block stained with hematoxylin and eosin (H\&M) were made to select and mark representative areas of the tumor specimens, and the arrays were constructed as previously described (29).
Immunohistochemistry of TMA. Immunohistochemistry (IHC) was performed on three slides ( 3 cores/case) for each marker. Paraffin-TMAs, 3- $\mu$ m-thick sections, were deparaffinized and rehydrated as described previously (29). Slides were placed in $3 \%$ hydrogen peroxide three times for $5 \mathrm{~min}$, washed in water for $5 \mathrm{~min}$, then incubated for a day in a humidified chamber with one of the primary antibodies. The primary antibodies used in the present study were mouse monoclonal anti-PAR-4 (Santa Cruz, Inc., Santa Cruz, CA, USA; catalog sc-1666; 1:100), anti-HER2 (Dako Cytomation, catalog A0485; 1:2000), anti-EGFR (Novocastra, catalog NCL-EGFR-384; 1:100), anti-phospho-AKT(Ser473) (Cell Signaling, catalog 4051; 1:800), anti-ER (Neomarkers, clone SP1, 1:1000), anti-PR (Dako, clone 636, 1:2000) and anti-CK5,6 (Dako, clone D5/16B4, 1:100) used according to the manufacturer's recommendations. The optimal dilution was defined using well-known positive samples, and tested before staining the TMA slides. The slides were washed in PBS and subsequently incubated with biotinylated anti-IgG for $20 \mathrm{~min}$, then with streptavidin-biotin peroxidase LSAB kit (Dako ${ }^{\circledR}$, Carpinteria, CA, USA) in a humidified chamber. The immunostaining was performed by incubating slides in diaminobenzidine (Dako) solution containing $1 \mu 1$ of chromogen per $50 \mu 1$ of buffer substrate for $5 \mathrm{~min}$. After chromogen development, the slides were washed, dehydrated with alcohol and xylene, and mounted with cover slips using a permanent mounting medium.

Evaluation of immunohistochemistry. Immunohistochemical evaluation was semiquantitative for all markers except for pAKT and PAR-4. Only clear staining of the tumor cells were considered positive and scored based on staining intensity and percentage of stained cells, which varied for each marker. Following scores used in the literature ER and PR were evaluated by the percentage and intensity of stained nucleus (30), CK5,6 and EGFR were considered positive when staining was observed in $\geq 1 \%$ of the tumor cells (31), tumors were considered positive for HER 2 over-expression when $\geq 10 \%$ of the tumor cells showed membranous immunostainning (32). A quantitative analysis was performed for the expression of pAKT and PAR-4 using the image capture system, Automated Cellular Imaging System (ACIS ${ }^{\circledR}$ III, Dako, K0690). Two TMA slides for each marker were scanned for image capture. The parameters were established regarding the intensity and area of brown staining captured for two to five areas in each case. A numerical value corresponding to the staining intensity multiplied by the area of brown staining divided by the total area analyzed was obtained for each circular area. For each tissue fragment, the final numerical value corresponding to the mean value of the 2-5 areas analyzed was determined. Tissue cores with less than $50 \%$ of the original tissue left on the slides after IHC were not used for the scoring of the stains.

Immunophenotypical classification. Breast tumors were stratified in four subtypes based on the immunohistochemical expression of estrogen receptor (ER), progesterone receptor (PR), HER2 and cyrokeratin 5,6 (CK5,6): luminal A (ERpositive, PR-positive, HER2-negative); luminal B (ER-positive and/or PR-positive, HER2-positive); HER over-exprression (ER-negative, PR-negative, HER2-positive); and triple-negative 
Table I. Sample description.

\begin{tabular}{|c|c|c|c|}
\hline Variable & Categories & $\mathrm{n}$ & $\%$ \\
\hline \multirow[t]{5}{*}{ Stage (TNM) } & Stage I & 71 & 6.1 \\
\hline & Stage II & 440 & 37.9 \\
\hline & Stage III & 527 & 45.5 \\
\hline & Stage IV & 108 & 9.3 \\
\hline & Not available & 15 & 1.3 \\
\hline \multirow[t]{3}{*}{ Lymph node metastasis } & No & 368 & 31.7 \\
\hline & Yes & 762 & 65.6 \\
\hline & Not available & 31 & 2.7 \\
\hline \multirow[t]{4}{*}{ Scarff-Bloom-Richardson } & Grade 1 & 169 & 14.6 \\
\hline & Grade 2 & 670 & 57.7 \\
\hline & Grade 3 & 319 & 27.5 \\
\hline & Not available & 3 & 0.3 \\
\hline \multirow[t]{4}{*}{ Nuclear grade } & Grade 1 & 17 & 1.5 \\
\hline & Grade 2 & 374 & 32.2 \\
\hline & Grade 3 & 766 & 66.0 \\
\hline & Not available & 4 & 0.3 \\
\hline \multirow[t]{3}{*}{ Estrogen receptor } & Negative & 354 & 30.5 \\
\hline & Positive & 716 & 61.7 \\
\hline & Not available & 91 & 7.8 \\
\hline \multirow[t]{3}{*}{ Progesterone receptor } & Negative & 572 & 49.3 \\
\hline & Positive & 469 & 40.4 \\
\hline & Not available & 120 & 10.3 \\
\hline \multirow[t]{3}{*}{ HER2 } & Negative & 840 & 72.4 \\
\hline & Positive & 141 & 12.1 \\
\hline & Not available & 180 & 15.5 \\
\hline
\end{tabular}

(ER-negative, PR-negative, HER2-negative, and/or CK5,6positive) (33).

Cell culture conditions. The MCF10A cells were obtained from the American Type Culture Collection (ATCC). The MCF10A cells were cultured at $37^{\circ} \mathrm{C}$ in an atmosphere of $5 \%$ $\mathrm{CO}_{2}, 95 \%$ air in F12/DMEM supplemented with 5\% horse serum, $50 \mathrm{ng} / \mathrm{ml}$ epidermal growth factor (EGF), $10 \mu \mathrm{g} / \mathrm{ml}$ insulin, $0.5 \mu \mathrm{g} / \mathrm{ml}$ hydrocortisone, $100 \mathrm{IU} / \mathrm{ml}$ penicillin, $100 \mu \mathrm{g} / \mathrm{ml}$ streptomycin, and $0.1 \mu \mathrm{g} / \mathrm{ml}$ cholera toxin.

Morphogenesis assay and immunofluorescence. MCF10A cells were grown in monolayers until they reach $100 \%$ confluence, then were trypsinized to obtain a suspension containing single cells. MCF10A cells $\left(2 \times 10^{3}\right)$ in media containing $3 \%$ of growth factor-reduced Matrigel (BD Biosciences) were plated in 8-well chamber slides onto a bed of $30 \mu 1$ of growth factor-reduced Matrigel, as described by Debnath et al (34). The expression of PAR-4 and activated caspase 3 in the acini structures was analyzed by immunofluorescence on days 3, 5, 7 and 10 . The medium containing 3\% Matrigel was replaced every 3 days. Immunofluorescence was performed as described by Debnath et al (34) with a few modifications, including permeabilization with $0.5 \%$ Triton $\mathrm{X}-100$ for $45 \mathrm{~min}$ and overnight incubation with primary antibodies at room temperature. The acini

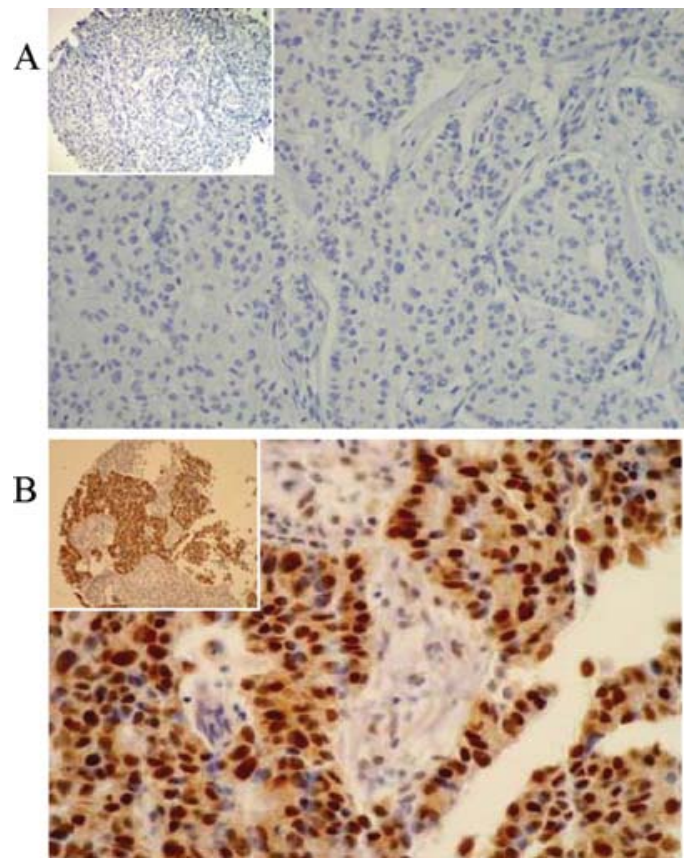

Figure 1. PAR-4 immunohistochemical staining in primary breast tumor samples. (A) Representative photomicrography from a TMA core of negative staining (original magnification $\mathrm{x} 40$ and $\mathrm{x} 400$ respectively). (B) Representative photomicrography from a TMA core of positive staining (original magnification $\mathrm{x} 40$ and $\mathrm{x} 400$ respectively).

structures were stained with mouse anti-PAR-4 monoclonal antibody (Santa Cruz, Inc., catalog sc-1666; 1:50) and/or a rabbit anti-activated-caspase 3 polyclonal antibody (Cell Signaling Technology, Inc., catalog 9661). The conjugated secondary anti-mouse-Alexa Fluor 546 and anti-rabbit-Alexa Fluor 488 were purchased from Invitrogen and diluted 1:300. Nuclear staining was performed with Hoechst 33342 (Invitrogen) for $15 \mathrm{~min}$. A Zeiss LSM Meta 510 scanning confocal microscope was used for immunofluorescence analysis and image capture.

Statistical methods. Median values of PAR-4 expression according to clinical and pathological variables were compared by means of Kruskal-Wallis and Mann-Whitney tests. The Spearman's coefficient (rho) assessed correlation between PAR-4 and pAKT expressions. For survival analysis, PAR-4 was classified as negative or positive. ROC curve defined the cut off point and death was set as the event. Ten-year disease-free survival and overall survival rates were calculated based on the Kaplan-Meier method and the curves were compared using the log-rank test. Significance level was set at $5 \%$ in all tests. Statistical analyses were performed using SPSS software 15.0 (SPSS Inc., Chicago, IL).

\section{Results}

In the present study investigating PAR-4 protein expression in breast cancer, IHC on TMAs containing 1,161 primary breast tumor specimens were performed using an antibody against the PAR-4 protein. The immunoreactivity scoring was based on the number of tumor cells displaying nuclear PAR-4 immunostaining. A representative example is shown in Fig. 1. PAR-4 staining was assessable in 995 cases on 
Table II. Nuclear PAR-4 expression according to tumor stage and biomolecular markers.

\begin{tabular}{|c|c|c|c|c|}
\hline Variable & Category & $\mathrm{n}$ & $\begin{array}{l}\text { PAR-4 expression } \\
\text { (median value) }\end{array}$ & P-value \\
\hline \multirow[t]{3}{*}{ Tumor size } & $\leq 2.0 \mathrm{~cm}$ & 149 & 31.3 & \multirow[t]{3}{*}{ KW: 0.835} \\
\hline & $2.1-5.0 \mathrm{~cm}$ & 510 & 27.1 & \\
\hline & $>5.0 \mathrm{~cm}$ & 291 & 26.7 & \\
\hline \multirow[t]{2}{*}{ Lymph node metastasis } & No & 314 & 28.4 & \multirow[t]{2}{*}{ MW: 0.633} \\
\hline & Yes & 652 & 27.3 & \\
\hline \multirow[t]{4}{*}{ Stage (TNM) } & Stage I & 54 & 25.6 & \multirow[t]{4}{*}{ KW: 0.145} \\
\hline & Stage II & 385 & 31.0 & \\
\hline & Stage III & 451 & 26.0 & \\
\hline & Stage IV & 91 & 26.8 & \\
\hline \multirow[t]{3}{*}{ Scarff-Bloom-Richardson } & Grade 1 & 134 & 21.2 & \multirow[t]{3}{*}{ KW: $<0.001$} \\
\hline & Grade 2 & 574 & 25.8 & \\
\hline & Grade 3 & 284 & 36.2 & \\
\hline \multirow[t]{3}{*}{ Nuclear grade } & Grade 1 & 12 & 5.2 & \multirow[t]{3}{*}{ KW: $<0.001$} \\
\hline & Grade 2 & 309 & 19.3 & \\
\hline & Grade 3 & 670 & 32.6 & \\
\hline \multirow[t]{2}{*}{ Estrogen receptor } & Negative & 315 & 25.6 & \multirow[t]{2}{*}{ MW: 0.526} \\
\hline & Positive & 648 & 28.5 & \\
\hline \multirow[t]{2}{*}{ Progesterone receptor } & Negative & 491 & 26.7 & \multirow[t]{2}{*}{ MW: 0.087} \\
\hline & Positive & 431 & 31.0 & \\
\hline \multirow[t]{2}{*}{ HER2 } & Negative & 731 & 25.3 & \multirow[t]{2}{*}{ MW: $<0.001$} \\
\hline & Positive & 131 & 38.5 & \\
\hline \multirow[t]{2}{*}{ EGFR } & Negative & 790 & 27.2 & \multirow[t]{2}{*}{ MW: 0.069} \\
\hline & Positive & 182 & 35.1 & \\
\hline
\end{tabular}

KW, Kruskal Wallis test. MW, Mann-Whitney test.

the TMA blocks. PAR-4 expression ranged from 0 to 97.4 according to ACIS analysis (median value 27.7).

Table II shows the relationship between PAR-4 protein expression and clinicopathological characteristics. There were no differences in PAR-4 expression according to tumor size, nodal status, or clinical stage. However, there was a statistically significant decrease in PAR-4 expression in lowgrade tumors according to the Scarff-Bloom-Richardson system $(P=0.001)$ and nuclear grade $(P=0.001)$. High expression of PAR-4 protein was observed in positive HER2 $(\mathrm{P}=0.001)$. However, no associations were observed between PAR-4 expression and estrogen receptor status $(\mathrm{P}=0.526)$ or progesterone receptor status $(\mathrm{P}=0.087)$. Tumors positive for EGFR had higher PAR-4 expression when compared with those negative for EGFR. This difference was near the significance level $(\mathrm{P}=0.069)$. A positive but weak correlation was observed between PAR-4 and pAKT expression $(\varrho=0.225$; $\mathrm{P}=0.001)$.

Table III shows the 10-year overall survival (OS) and disease-free survival (DFS) analysis. There was a significant difference in OS rates according to tumor stage $(\mathrm{P}=0.001)$, lymph node status $(\mathrm{P}=0.001)$, nuclear grade $(\mathrm{P}=0.001)$, estrogen receptor status $(\mathrm{P}=0.001)$, progesterone receptor status $(\mathrm{P}=0.001)$, HER2 status $(\mathrm{P}=0.005)$, EGFR status $(\mathrm{P}=0.002)$ and nuclear PAR-4 status $(\mathrm{P}=0.041)$. The DFS analysis showed differences according to tumor stage $(\mathrm{P}=0.001)$, lymph node status $(\mathrm{P}=0.001)$, Scarff-Bloom-Richardson grading $(\mathrm{P}=0.001)$, estrogen receptor status $(\mathrm{P}=0.002)$, progesterone receptor status $(\mathrm{P}=0.001)$, HER2 status $(\mathrm{P}=0.032)$ and $\mathrm{EGFR}$ status $(\mathrm{P}=0.001)$. However, no differences was observed in the DFS rates according to nuclear PAR-4 expression $(\mathrm{P}=0.138)$.

Kaplan-Meier survival curves were generated to assess the potential prognostic value of PAR-4 protein expression in breast cancer. Nuclear PAR-4 protein expression was a prognostic predictor of OS, but not of DFS in the group of breast cancer patients analyzed. As shown in Fig. 2, significant differences among survival curves by log-rank was observed for OS (Fig. 2A, P=0.041). We also assessed the power of PAR-4 expression to predict OS and DFS in our breast 
Table III. Ten-year overall survival and disease-free survival analysis.

\begin{tabular}{|c|c|c|c|c|c|c|c|}
\hline \multirow[b]{2}{*}{ Variable } & \multirow[b]{2}{*}{ Category } & \multicolumn{3}{|c|}{$\begin{array}{l}\text { 10-year overall survival } \\
\text { (cumulative survival - \%) }\end{array}$} & \multicolumn{3}{|c|}{$\begin{array}{l}\text { 10-year disease-free survival } \\
\text { (cumulative survival - \%) }\end{array}$} \\
\hline & & $\mathrm{n}$ & $\%$ & P-value & $\mathrm{n}$ & $\%$ & P-value \\
\hline \multirow[t]{4}{*}{ Stage } & Stage I & 71 & 82.7 & $<0.001$ & 70 & 80.0 & $<0.001$ \\
\hline & Stage II & 437 & 70.6 & & 434 & 70.5 & \\
\hline & Stage III & 523 & 35.8 & & 493 & 35.3 & \\
\hline & Stage IV & 108 & 1.9 & & - & & \\
\hline \multirow[t]{2}{*}{ Lymph node metastasis } & No & 366 & 69.1 & $<0.001$ & 355 & 73.1 & $<0.001$ \\
\hline & Yes & 756 & 39.3 & & 633 & 43.4 & \\
\hline \multirow[t]{3}{*}{ Scarff-Bloom-Richardson } & Grade 1 & 168 & 60.9 & $<0.001$ & 153 & 66.4 & $<0.001$ \\
\hline & Grade 2 & 657 & 48.3 & & 585 & 52.9 & \\
\hline & Grade 3 & 312 & 41.6 & & 256 & 48.1 & \\
\hline \multirow[t]{3}{*}{ Nuclear grade } & Grade 1 & 16 & 71.8 & 0.001 & 16 & 65.5 & 0.103 \\
\hline & Grade 2 & 368 & 54.0 & & 330 & 56.6 & \\
\hline & Grade 3 & 752 & 45.1 & & 647 & 52.2 & \\
\hline \multirow[t]{2}{*}{ Estrogen receptor } & Negative & 350 & 41.6 & $<0.001$ & 291 & 49.6 & 0.002 \\
\hline & Positive & 700 & 52.1 & & 626 & 56.6 & \\
\hline \multirow[t]{2}{*}{ Progesterone receptor } & Negative & 561 & 41.6 & $<0.001$ & 482 & 47.3 & $<0.001$ \\
\hline & Positive & 460 & 57.7 & & 419 & 60.6 & \\
\hline \multirow[t]{2}{*}{ HER2 } & Negative & 822 & 49.2 & 0.005 & 722 & 53.9 & 0.032 \\
\hline & Positive & 140 & 44.3 & & 120 & 48.5 & \\
\hline \multirow[t]{2}{*}{ EGFR } & Negative & 872 & 51.1 & 0.002 & 776 & 56.7 & $<0.001$ \\
\hline & Positive & 202 & 41.4 & & 164 & 41.6 & \\
\hline \multirow[t]{2}{*}{ PAR-4 } & Negative $(\leq 35)$ & 566 & 45.0 & 0.041 & 493 & 50.6 & 0.138 \\
\hline & Positive $(>35)$ & 409 & 53.7 & & 361 & 56.6 & \\
\hline \multirow[t]{2}{*}{ PAKT } & Negative $(\leq 90)$ & 532 & 50.8 & 0.027 & 477 & 57.0 & 0.080 \\
\hline & Positive $(>90)$ & 494 & 46.2 & & 419 & 49.8 & \\
\hline \multirow[t]{4}{*}{ PAR-4-PAKT interaction } & PAR-4 (-)/pAKT (-) & 309 & 47.6 & 0.040 & 276 & 54.8 & 0.231 \\
\hline & PAR-4 (-)/pAKT (+) & 240 & 42.7 & & 202 & 46.6 & \\
\hline & PAR-4 (+)/pAKT (-) & 192 & 53.7 & & 173 & 58.3 & \\
\hline & PAR-4 (+)/pAKT (+) & 214 & 53.2 & & 185 & 55.0 & \\
\hline \multirow[t]{4}{*}{ PAR-4-EGFR interaction } & PAR-4 (-)/EGFR (-) & 459 & 47.4 & 0.001 & 408 & 53.3 & $<0.001$ \\
\hline & PAR-4 (-)/EGFR (+) & 91 & 34.8 & & 71 & 34.5 & \\
\hline & PAR-4 (+)/EGFR (-) & 311 & 56.5 & & 280 & 60.5 & \\
\hline & PAR-4 (+)/EGFR (+) & 91 & 46.3 & & 76 & 45.2 & \\
\hline \multirow[t]{4}{*}{ PAR-4-HER2 interaction } & PAR-4 (-)/HER2 (-) & 432 & 46.3 & 0.003 & 379 & 51.5 & 0.058 \\
\hline & PAR-4 (-)/HER2 (+) & 59 & 35.7 & & 48 & 38.1 & \\
\hline & PAR-4 (+)/HER2 (-) & 281 & 55.2 & & 248 & 56.7 & \\
\hline & PAR-4 (+)/HER2 (+) & 71 & 50.5 & & 64 & 55.3 & \\
\hline
\end{tabular}

cancer population stratified based on the immunophenotype classification as luminal A, luminal B, HER2 positive and triple-negative tumors. Patients classified as luminal subtype A with tumors showing PAR-4 negative expression had a significant worse prognosis $(\mathrm{P}=0.028)$ than patients with luminal subtype A tumors positive for PAR-4 expression 

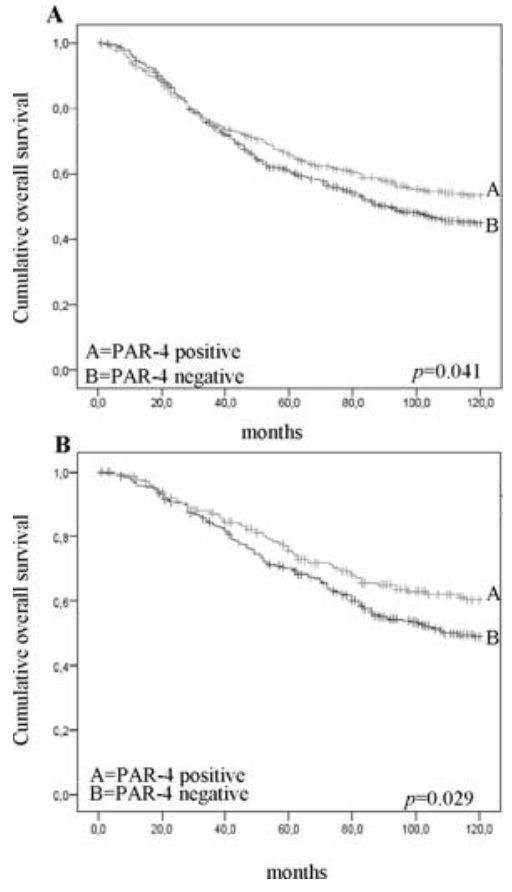

Figure 2. Kaplan-Meier curves for long-term survival in primary breast cancer patients, stratified according to PAR-4 protein expression. (A) Overall survival (all patients); (B) Overall survival (luminal subtype A patients). Tumors were classified as negative or positive for PAR-4 nuclear immunostaining.
(Fig 2B). No associations were observed for PAR-4 nuclear expression and the other breast cancer subtypes.

Since AKT activation, that can be displayed by EGFR and HER2 signaling pathways, has been associated with PAR-4 phosphorylation, cytoplasmic sequestration, and inhibition of its proapoptotic function, we also analyzed the prognostic value of PAR-4 in association with HER2, EGFR and pAKT protein expression. In our analysis, the positive status for HER2, EGFR, and pAKT alone was significantly associated with poor prognosis (Fig. 3A, C and E). In general, PAR-4 protein expression in association with HER2, EGFR or pAKT protein expression had a predictive prognostic value for both DFS and OS in the series of breast cancer patients analyzed. As shown in Fig. 3B, D and F, recurrence or death due to disease occurred earlier in patients with tumors negative for nuclear PAR-4 expression, that over-expressed HER2 (OS, $\mathrm{P}=0.003$; DFS, $\mathrm{P}=0.058$ ) or EGFR (OS, $\mathrm{P}=0.001$; DFS, $\mathrm{P}=0.001$ ), or exhibited AKT activation (OS, $\mathrm{P}=0.04$; DFS, $\mathrm{P}=0.231$ ).

Using three-dimensional (3D) cell culture we also evaluated the expression pattern of the PAR-4 during morphogenesis of MCF10A cells. As shown in Fig. 4, high levels of PAR-4 expression were displayed by the cells within the acini lumen. PAR-4 expression on these cells was only partially co-expressed with activated caspase- 3 .
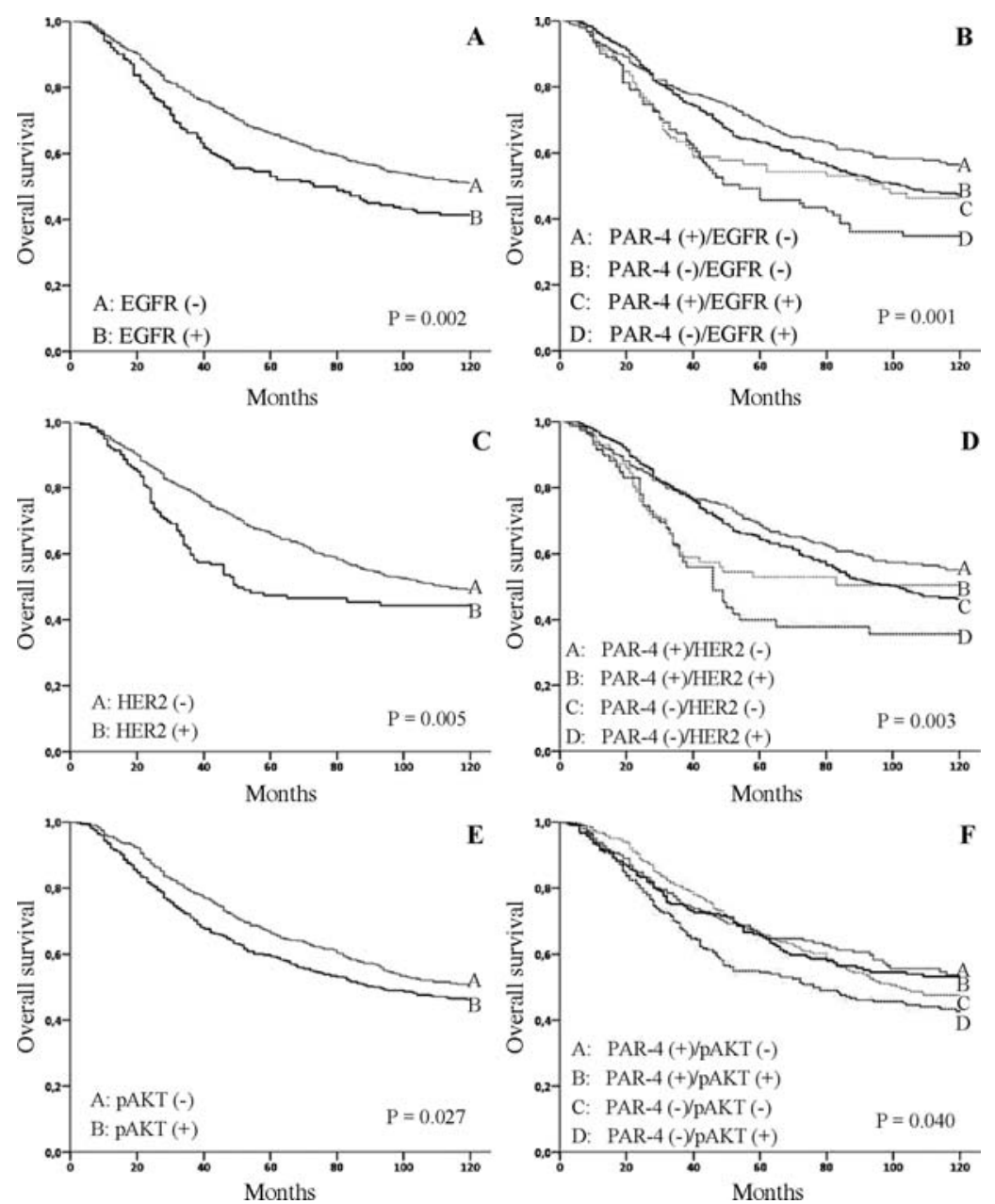

Figure 3. Kaplan-Meier curves for long-term overall survival in breast cancer patients stratified according to: (A) EGFR protein expression; (B) Nuclear PAR-4 and EGFR protein expression; (C) HER2 protein expression; (D) Nuclear PAR-4 and HER2 protein expression; (E) pAKT protein expression; (F) Nuclear PAR-4 and pAKT protein expression. 

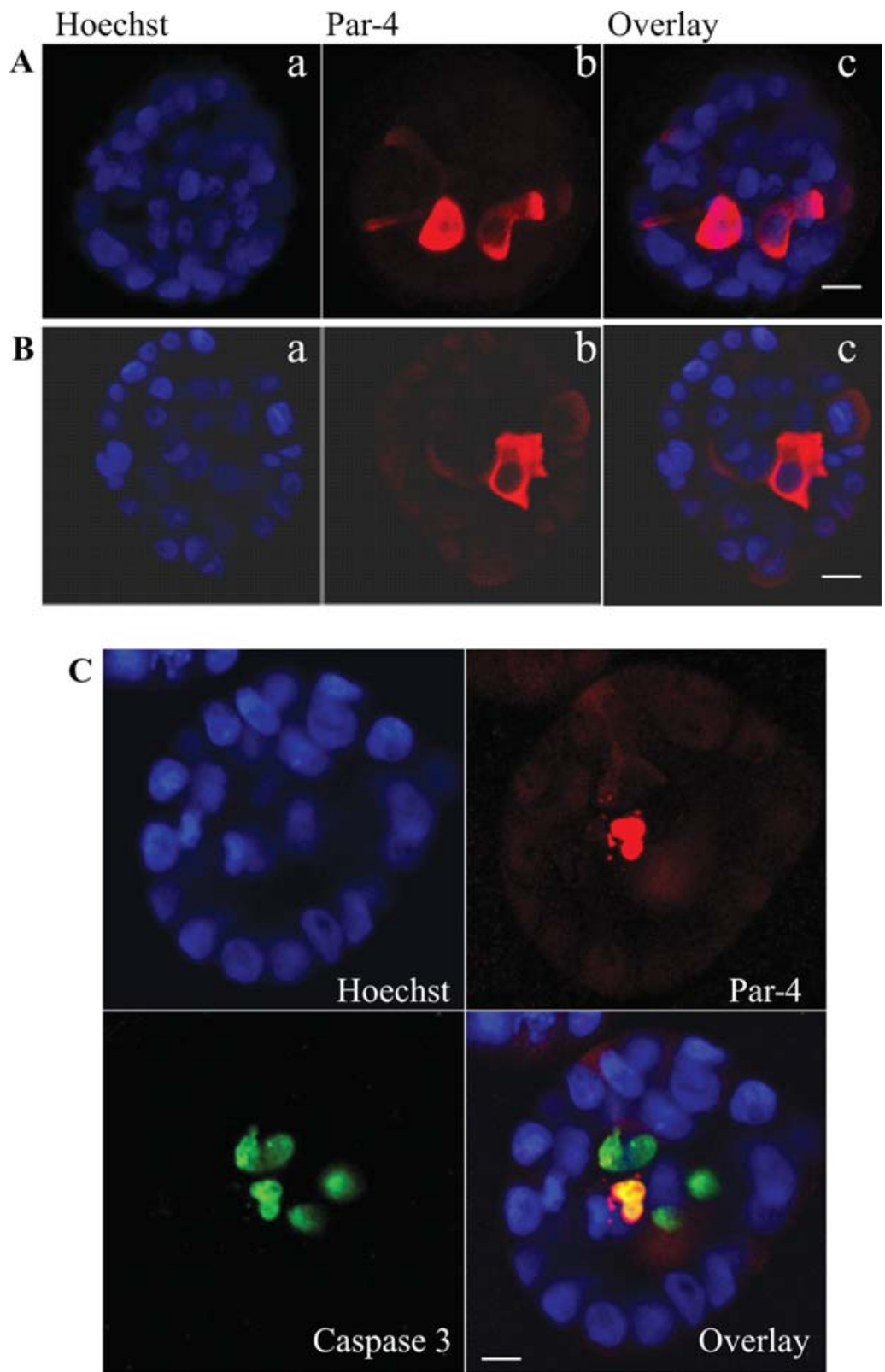

Figure 4. Expression of PAR-4 and activated caspase 3 in MCF10A cells grown in three-dimensional (3D) cell culture. Representative confocal microscopic images of MCF10A cells cultured in growth factor reduced Matrigel for 5 (A) and 7 (B) days and examined for PAR-4 protein expression (red) by immunofluorescence. Nuclei were contrastained with Hoechst (a, blue); overlay (c). (B) Day 7 MCF10A acini were immunostained with anti-PAR-4 (b, red) and anti-cleaved caspase 3 (c, green). Nuclei was contrastained with Hoechst (a, blue); overlay (d). Equatorial cross sections of the acini were obtained using a Zeiss LSM Meta 510 confocal microscope system (scale bar: A, $15 \mu \mathrm{m}$; B, $25 \mu \mathrm{m}$; C, $50 \mu \mathrm{m}$ ).

\section{Discussion}

To our knowledge, our study represents the first large, systematic investigation of PAR-4 protein expression in primary breast tumors. In our series of primary breast cancer patients, we observed that nuclear PAR-4 down-regulation was associated with poor breast cancer prognosis. In addition, we found that PAR-4 down-regulation showed to be a prognostic factor for luminal subtype A breast cancer, suggesting a functional association between the presence of ER and PAR-4 expression. PAR-4 has been shown to be ubiquitously expressed in different tissues (19) and PAR-4 knockout mice are prone to develop tumors of the liver, lung, urinary bladder, but with an increased prevalence of hormone-dependent tumors of the endometrium and prostate (35). Carcinomas of the mammary gland was observed in PAR-4 heterozygous (PAR-4+/-) animals (35). It is interesting to note that estradiol reduces PAR-4 expression in mouse uterus, which corroborates the association between PAR-4 down-regulation and high frequency of endometrial carcinomas in PAR-4 knockout mice (35). Further studies to evaluate the role played by estrogens on the transcriptional regulation of PAR-4 in normal and breast cancer cells are required.

By combining the PAR-4 nuclear status with three prognostic proteins (HER2, EGFR, and pAKT) we also provide information for a more powerful prediction of disease survival in breast cancer patients. Translocation of PAR-4 to the nucleus has been shown to be essential for the PAR-4 
apoptotic function $(6,16)$. Gurumurthy et al $(16)$ demonstrated that cancer-cell apoptosis elicited by PAR-4 requires its phosphorylation and nuclear translocation. These authors also showed that both Fas/FasL translocation to the cell membrane and inhibition of NF- $\mathrm{KB}$ by PAR-4 is dependent on the phos-phorylaion of the T155 residue located on the PAR-4 SAC domain. The PAR-4 SAC domain can translocate to the nucleus in both normal and cancer cells; however, it elicits apoptosis specifically in cancer cells through phosphorylation of the T155 residue by PKA. Moreover, cancer cells with deficient nuclear translocation of PAR-4, such as MCF-7 breast cancer cells are resistant to its apoptotic function $(6,16)$. On the other hand, the survival kinase AKT that is known to phosphorylate and inactivate several pro-apoptotic proteins (36) was found to bind and phosphorylate PAR-4 at S249 residue located outside the SAC domain $(17,18)$. In different cancer cell lines established from prostate, cervical and breast cancers, activated AKT leads to PAR-4 phosphorylation and cytoplasmic retention by the chaperone 14-3-3 (18). The PTEN, a dual phosphatase that antagonizes PI-3K function is one of the main negative regulators of AKT (37). AKT activation is a frequent event in cancer cells that harbor genetic alteration leading to PTEN inactivation, which is observed in breast tumors (38). In addition, oncogene activation and growth factor overexpression such as HER2 and EGFR that leads to the activation of downstream signaling components such as MAPK (proliferation) and PI-3K/AKT (survival) are observed and have an established prognostic and predictive value in breast cancer (39). Activated AKT has been observed in HER2-positive breast tumors (40), suggesting that the axis PI-3K/AKT is activated in these tumors. Thus PAR-4 negative nuclear staining due to AKT activation could be associated with ERBB2 or EGFR over-expression in breast tumor biopsies. Our study supports this hypothesis showing a close association between HER2, EGFR over-expression or AKT activation and nuclear PAR-4 down-regulation and the disease outcome of the patients. In the present large series of breast cancer patients, our findings show that HER2, EGFR and pAKT protein expression are significantly associated with short disease-free survival and overall survival, but the prognosis was even worse for HER2-positive, EGFR-positive or pAKT-positive breast cancer patients with tumors showing negative nuclear PAR-4 expression. These findings indicate that PAR-4 down-regulation or functional inactivation may protect breast tumor cells from cell death enhancing the malignant phenotype and suggest a prognostic role for PAR-4 in breast cancer.

Three-dimensional (3D) cell culture of the spontaneously immortalized cell line MCF10A is a well-established model system to study breast epithelial cell biology and morphogenesis $(41,42)$. Using this system, we provide preliminary results showing that PAR-4 is highly expressed in the MCF10A cells inside the acini structure (Fig. 4). During the morphogenesis of MCF10A cells in 3D cell culture, the cells within the lumen show apoptotic activity demonstrated by caspase- 3 activation $(34,42)$. Our results show co-expression of PAR-4 and activated caspase 3 in some cells only. Loss of interaction between the cells and the components of the extra-cellular matrix leading to anoikis is required for lumen formation
$(42,43)$. Loss of cell adhesion could be the factor that induces PAR-4 expression, which marks and sensitizes mammary epithelial cells for apoptosis. It is interesting to note that the morphogenesis of MCF10A can be altered by oncogene activation, such as HER2 over-expression that leads to increased proliferation and disruption of lumen formation $(42,44)$. It is possible that the production of filled acinar structures by HER2 over-expression could be, at least in part, due to its effect on PAR-4 inhibition. Although preliminary, our results indicate that PAR-4 may play a role in the process of mammary gland morphogenesis. New studies to investigate the role of PAR-4 in mammary morphogenesis and its connection with HER2 activation are warranted.

The findings presented in this work provide evidence that nuclear PAR-4 down-regulation is a frequent event associated with breast cancer progression. Besides its potential to be a target for anticancer strategies, PAR- 4 could be considered an end marker of the functionality of the PI-3K/AKT pathways for therapeutic approaches targeting EGFR, HER2 or AKT in breast cancer.

\section{Acknowledgments}

This work was supported by FAPESP - Fundação de Amparo a Pesquisa do Estado de São Paulo (grant no. 06/01026-0). This work was also supported in part by CNPq (304949/2006-0). We thank Dr Ana Lucia Garippo from Rede Multiusuários HC-FMUSP (FAPESP no. 04/08908-2) for excellent technical assistance with the confocal immunofluorescence image capture.

\section{References}

1. Hanahan D and Weinberg RA: The hallmarks of cancer. Cell 100: 57-70, 2000.

2. Call JA, Eckhardt SG and Camidge DR: Targeted manipulation of apoptosis in cancer treatment. Lancet Oncol 9: 1002-1011, 2008.

3. Zhao Y and Rangnekar VM: Apoptosis and tumor resistance conferred by Par-4. Cancer Biol Ther 7: 1867-1874, 2008.

4. Sells SF, Han SS, Muthukkumar S, Maddiwar N, Johnstone R, Boghaert E, Gillis D, Liu G, Nair P, Monnig S, Collini P, Mattson MP, Sukhatme VP, Zimmer SG, Wood DP Jr, McRoberts JW, Shi Y and Rangnekar VM: Expression and function of the leucine zipper protein Par-4 in apoptosis. Mol Cell Biol 17: 3823-3832, 1997.

5. Johnstone RW, Tommerup N, Hansen C, Vissing H and Shi Y: Mapping of the human PAR-4 (par-4) gene to chromosome 12q21. Genomics 53: 241-243, 1998.

6. El-Guendy N, Zhao Y, Gurumurthy S, Burikhanov R and Rangnekar VM: Identification of a unique core domain of par-4 sufficient for selective apoptosis induction in cancer cells. Mol Cell Biol 23: 5516-5525, 2003.

7. Sells SF, Wood DP Jr, Joshi-Barve SS, Muthukumar S, Jacob RJ, Crist SA, Humphreys S and Rangnekar VM: Commonality of the gene programs induced by effectors of apoptosis in androgendependent and -independent prostate cells. Cell Growth Differ 5: 457-466, 1994.

8. Ranganathan P and Rangnekar VM: Regulation of cancer cell survival by Par-4. Ann NY Acad Sci 1059: 76-85, 2005.

9. Johnstone RW, See RH, Sells SF, Wang J, Muthukkumar S, Englert C, Haber DA, Licht JD, Sugrue SP, Roberts T, Rangnekar VM and Shi Y: A novel repressor, par-4, modulates transcription and growth suppression functions of the Wilms' tumor suppressor WT1. Mol Cell Biol 16: 6945-6956, 1996.

10. Page G, Kögel D, Rangnekar V and Scheidtmann KH: Interaction partners of Dlk/ZIP kinase: co-expression of Dlk/ZIP kinase and Par-4 results in cytoplasmic retention and apoptosis. Oncogene 18: 7265-7273, 1999. 
11. Cheema SK, Mishra SK, Rangnekar VM, Tari AM, Kumar R and Lopez-Berestein G: Par-4 transcriptionally regulates Bcl-2 through a WT1-binding site on the bcl-2 promoter. J Biol Chem 278: 19995-20005, 2003.

12. Garcia-Cao I, Lafuente MJ, Criado LM, Diaz-Meco MT, Serrano $\mathrm{M}$ and Moscat J: Genetic inactivation of Par4 results in hyperactivation of NF-kappaB and impairment of JNK and p38. EMBO Rep 4: 307-312, 2003.

13. Qiu G, Ahmed M, Sells SF, Mohiuddin M, Weinstein MH and Rangnekar VM: Mutually exclusive expression patterns of Bcl-2 and Par-4 in human prostate tumors consistent with down-regulation of Bcl-2 by Par-4. Oncogene 18: 623-631, 1999.

14. Boehrer S, Chow KU, Beske F, Kukoc-Zivojnov N, Puccetti E, Ruthardt M, Baum C, Rangnekar VM, Hoelzer D, Mitrou PS and Weidmann E: In lymphatic cells par-4 sensitizes to apoptosis by down-regulating bcl-2 and promoting disruption of mitochondrial membrane potential and caspase activation. Cancer Res 62: 1768-1775, 2002.

15. Chakraborty M, Qiu SG, Vasudevan KM and Rangnekar VM: Par-4 drives trafficking and activation of Fas and Fasl to induce prostate cancer cell apoptosis and tumor regression. Cancer Res 61: 7255-7263, 2001.

16. Gurumurthy S, Goswami A, Vasudevan KM and Rangnekar VM: Phosphorylation of Par-4 by protein kinase A is critical for apoptosis. Mol Cell Biol 25: 1146-1161, 2005

17. Goswami A, Ranganathan P and Rangnekar VM: The phosphoinositide 3-kinase/Akt1/Par-4 axis: a cancer-selective therapeutic target. Cancer Res 66: 2889-2892, 2006.

18. Goswami A, Burikhanov R, De Thonel A, Fujita N, Goswami M, Zhao Y, Eriksson JE, Tsuruo T and Rangnekar VM: Binding and phosphorylation of par-4 by akt is essential for cancer cell survival. Mol Cell 20: 33-44, 2005.

19. Boghaert ER, Sells SF, Walid AJ, Malone P, Williams NM, Weinstein MH, Strange R and Rangnekar VM: Immunohistochemical analysis of the proapoptotic protein Par-4 in normal rat tissues. Cell Growth Differ 8: 881-890, 1997.

20. Gurumurthy S and Rangnekar VM: Par-4 inducible apoptosis in prostate cancer cells. J Cell Biochem 91: 504-512, 2004.

21. Díaz-Meco MT, Municio MM, Frutos S, Sanchez P, Lozano J, Sanz L and Moscat J: The product of par-4, a gene induced during apoptosis, interacts selectively with the atypical isoforms of protein kinase C. Cell 86: 777-786, 1996.

22. El Affar B, Luke MP, Gay F, Calvo D, Sui G, Weiss RS, Li E and Shi Y: Targeted ablation of Par-4 reveals a cell type-specific susceptibility to apoptosis-inducing agents. Cancer Res 66 : 3456-3462, 2006.

23. Chan SL, Tammariello SP, Estus S and Mattson MP: Prostate apoptosis response-4 mediates trophic factor withdrawal-induced apoptosis of hippocampal neurons: actions prior to mitochondrial dysfunction and caspase activation. J Neurochem 73: 502-512, 1999.

24. Boehrer S, Chow KU, Puccetti E, Ruthardt M, Godzisard S, Krapohl A, Schneider B, Hoelzer D, Mitrou PS, Rangnekar VM and Weidmann E: Deregulated expression of prostate apoptosis response gene-4 in less differentiated lymphocytes and inverse expressional patterns of par- 4 and bcl-2 in acute lymphocytic leukemia. Hematol J 2: 103-107, 2001.

25. Cook J, Krishnan S, Ananth S, Sells SF, Shi Y, Walther MM, Linehan WM, Sukhatme VP, Weinstein MH and Rangnekar VM: Decreased expression of the pro-apoptotic protein Par-4 in renal cell carcinoma. Oncogene 18: 1205-1208, 1999.

26. Moreno-Bueno G, Fernandez-Marcos PJ, Collado M, Tendero MJ, Rodriguez-Pinilla SM, Garcia-Cao I, Hardisson D, DiazMeco MT, Moscat J, Serrano M and Palacios J: Inactivation of the candidate tumor suppressor par-4 in endometrial cancer. Cancer Res 67: 1927-1934, 2007.

27. Ahmed MM, Sheldon D, Fruitwala MA, Venkatasubbarao K, Lee EY, Gupta S, Wood C, Mohiuddin M and Strodel WE: Downregulation of PAR-4, a pro-apoptotic gene, in pancreatic tumors harboring K-ras mutation. Int J Cancer 122: 63-70, 2008.
28. Gao S, Wang H, Lee P, Melamed J, Li CX, Zhang F, Wu H, Zhou L and Wang Z: Androgen receptor and prostate apoptosis response factor-4 target the c-FLIP gene to determine survival and apoptosis in the prostate gland. J Mol Endocrinol 36: 463-483, 2006

29. Nagai MA, Fregnani JH, Netto MM, Brentani MM and Soares FA: Down-regulation of PHLDA1 gene expression is associated with breast cancer progression. Breast Cancer Res Treat 106: 49-56, 2007.

30. Allred DC, Harvey JM, Berardo M and Clark GM: Prognostic and predictive factors in breast cancer by immunohistochemical analysis. Mod Pathol 11: 155-168, 1998.

31. Nielsen TO, Hsu FD, Jensen K, Cheang M, Karaca G, Hu Z, Hernandez-Boussard T, Livasy C, Cowan D, Dressler L, Akslen LA, Ragaz J, Gown AM, Gilks CB, van de Rijn M and Perou CM: Immunohistochemical and clinical characterization of the basal-like subtype of invasive breast carcinoma. Clin Cancer Res 10: 5367-5374, 2004.

32. Diaz LK, Gupta R, Kidwai N, Sneige N and Wiley EL: The use of TMA for interlaboratory validation of FISH testing for detection of HER 2 gene amplification in breast cancer. J Histochem Cytochem 52: 501-507, 2004.

33. Carey LA, Dees EC, Sawyer L, Gatti L, Moore DT, Collichio F, Ollila DW, Sartor CI, Graham ML and Perou CM: The triple negative paradox: primary tumor chemosensitivity of breast cancer subtypes. Clin Cancer Res 13: 2329-2334, 2007.

34. Debnath J, Muthuswamy SK and Brugge JS: Morphogenesis and oncogenesis of MCF-10A mammary epithelial acini grown in three-dimensional basement membrane cultures. Methods 30: 256-268, 2003

35. García-Cao I, Duran A, Collado M, Carrascosa MJ, MartínCaballero J, Flores JM, Diaz-Meco MT, Moscat J and Serrano M: Tumour-suppression activity of the proapoptotic regulator Par4. EMBO Rep 6: 577-583, 2005.

36. Fresno Vara JA, Casado E, De Castro J, Cejas P, Belda-Iniesta C and González-Barón M: PI3K/Akt signalling pathway and cancer. Cancer Treat Rev 30: 193-204, 2004.

37. Sansal I and Sellers WR: The biology and clinical relevance of the PTEN tumor suppressor pathway. J Clin Oncol 22: 2954-2963, 2004.

38. Chung MJ, Jung SH, Lee BJ, Kang MJ and Lee DG: Inactivation of the PTEN gene protein product is associated with the invasiveness and metastasis, but not angiogenesis, of breast cancer. Pathol Int 54: 10-15, 2004.

39. Lin NU and Winer EP: New targets for therapy in breast cancer: small molecule tyrosine kinase inhibitors. Breast Cancer Res 6: 204-210, 2004

40. Tokunaga E, Kimura Y, Oki E, Ueda N, Futatsugi M, Mashino K, Yamamoto M, Ikebe M, Kakeji Y, Baba H and Maehara Y: Akt is frequently activated in HER2/neu-positive breast cancers and associated with poor prognosis among hormone-treated patients. Int J Cancer 118: 284-289, 2006.

41. Lee GY, Kenny PA, Lee EH and Bissell MJ: Three-dimensional culture models of normal and malignant breast epithelial cells. Nat Methods 4: 359-365, 2007.

42. Debnath J, Mills KR, Collins NL, Reginato MJ, Muthuswamy SK and Brugge JS: The role of apoptosis in creating and maintaining luminal space within normal and oncogene-expressing mammary acini. Cell 111: 29-40, 2002

43. Green KA and Streuli CH: Apoptosis regulation in the mammary gland. Cell Mol Life Sci 61: 1867-1883, 2004.

44. Muthuswamy SK, Li D, Lelievre S, Bissell MJ and Brugge JS: ErbB2, but not ErbB1, reinitiates proliferation and induces luminal repopulation in epithelial acini. Nat Cell Biol 3: 785-792, 2001. 